\title{
Analysis of the polymeric abrasive paste regeneration for abrasive flow machining
}

\author{
Agnieszka Nowacka), *) (ORCID ID: 0000-0002-2796-9626), Tomasz Klepka ${ }^{1)}{ }^{(0000-0001-9182-0845) ~}$ \\ DOI: dx.doi.org/10.14314/polimery.2021.7.6
}

\begin{abstract}
The influence of conditions and the sifting process efficiency of the worn-out polymeric abrasive paste containing silica $\left(\mathrm{SiO}_{2}\right)$ and polymer chips remaining after the surface treatment were investigated. The abrasive paste regeneration process consisted of sifting the used paste through sieves of a vibrating screen, on which abrasive grains and polymer chips were recovered. The diameter of the sieve holes determined the size of the recovered abrasive grains and polymer chips, on the size of which the efficiency of the process depended. The lowest efficiency of the sifting process was obtained using a sieve with the holes diameter equal to the diameter of the grain and the polymer chips of the given fraction. The highest efficiency of the sifting process was obtained for a sieve with a diameter of $0.032 \mathrm{~mm}$. The regenerated polymeric abrasive paste can be reused in the process of abrasive flow machining.
\end{abstract}

Keywords: polymeric abrasive paste, abrasive flow machining, efficiency of sifting, processing of polymer surfaces.

\section{Analiza regeneracji polimerowych past ściernych do obróbki przetłoczono- -ściernej}

Streszczenie: Zbadano wpływ warunków i wydajność procesu przesiewania zużytej polimerowej pasty ściernej zawierającej krzemionkę $\left(\mathrm{SiO}_{2}\right)$ i pozostałe po obróbce powierzchni wióry polimerowe. Proces regeneracji pasty ściernej polegał na przesianiu zużytej pasty przez sita przesiewacza wibracyjnego, na których odzyskiwano ziarna ścierne i wióry polimerowe. Średnica otworów sita determinowała wielkość odzyskanych ziaren ściernych i wiórów polimerowych, od których wielkości zależała wydajność procesu. Najmniejszą wydajność procesu przesiewania uzyskano stosując sito o średnicy otworów równej średnicy ziarna oraz wiórów polimerowych danej frakcji, a największą sito o średnicy 0,032 $\mathrm{mm}$. Zregenerowaną polimerową pastę ścierną można ponownie wykorzystać w procesie obróbki przetłoczono - ściernej.

Słowa kluczowe: polimerowe pasty ścierne, obróbka przetłoczno-ścierna, wydajność przesiewania, obróbka powierzchni polimerowych.

Polymeric materials are widely used in various fields of technology. More and more often they replace traditional construction materials used in the production of machines and mechanisms elements or are used as functional materials for abrasive flow machining [1, 2]. Therefore, the authors developed an effective finishing technique that improves the surface roughness of polymer products [3-5].

Abrasive flow machining (AFM) is an advanced finishing process used for deburring, polishing, or radiusing of edges and interior surfaces of hard-to-reach workpiece geometries in which special viscoelastic abrasives are

\footnotetext{
1) Lublin University of Technology, Faculty of Mechanical Engineering, Department of Technology and Polymer Processing, 36 Nadbystrzycka Str., 20-618 Lublin.

*) Author for correspondence: a.nowacka@pollub.pl
}

used [6]. One of the first studies of this advanced machining process was done by Rhoades [7, 8]. He explained the rules of the process in detail. Two opposing cylinders are used that clamp the workpiece between each other and seal the machining passage (Fig. 1). Hydraulically operated pistons inside the cylinders repeatedly press the abrasive medium back and forth through or across the workpiece to finish (see Fig. 1). One up and down piston movement corresponds to the duty cycle [9-11].

Wang et al. $[12,13]$ generally described the process as well as the abrasive paste used in it. The semi-solid abrasive paste consists of abrasive particles up to a content of $5-60$ vol. \%. and a polymeric carrier [10-13]. The viscosity of the abrasive paste is adjusted by adding oil and other additives. An alternative to the average paste with a high market price are polymeric materials that can provide the viscoelastic properties of the paste $[5,12]$. 


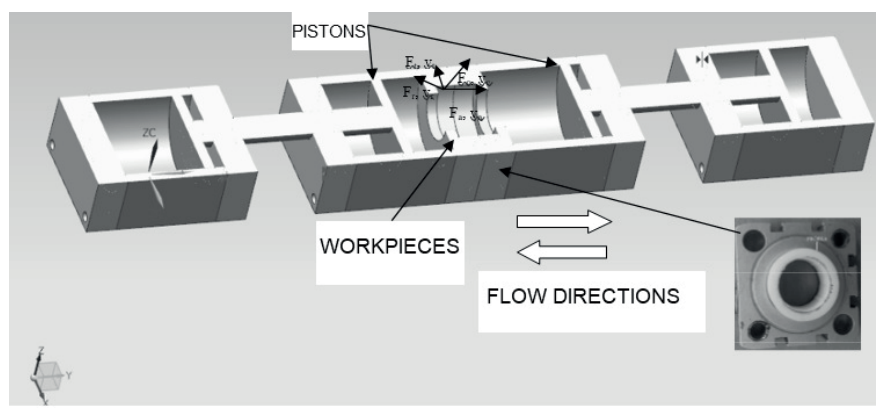

Fig. 1. The essence of abrasive flow machining consisting in forcing the abrasive paste through the workpiece; $F_{a}$ - the force with which the paste moves through the piston, $F_{r}$ - the axial force from the viscoelastic paste, $F_{t}$ - the perpendicular force from the viscoelastic paste $F_{c}$ - the total force of the abrasive grain interaction on the treated surface [3]

The most commonly used abrasives are silicon carbide, aluminum oxide or boron carbide [4, 13, 14]. Roughness or burrs are removed by alternating movement of the abrasive suspension along the surface and edge of the workpiece $[15,16]$. Abrasive paste wears when used in finishing processes where polymers do not assist in material removal. However, the used paste can be recovered in the sifting process $[17,18]$. After recovering, the carrier abrasive transfers pressure from the pistons to the abrasive particles [19-21]. The previously reworked abrasive absorbs the abraded material of the workpiece and transports it away from the place of its removal [22-24]. Consistent process efficiency and quality are ensured by invariable input parameters. However, the properties of the abrasive medium change under the influence of wear in the machining process [25]. In current studies, these changes in abrasive properties have not been systematically investigated or documented, except in our previous research [3].

This article presents an original method of selecting appropriate conditions for the sifting for worn-out abrasive polymer used for abrasive flow machining. The effectiveness of the abrasive grain sifting process of the applied abrasives (for $480 \mathrm{~h}$ ) for different sieve sizes was characterized and compared. The characteristics that generally affect the efficiency of the abrasive grain sifting process, such as the behavior, size and composition of the abrasive particles, were also quantified. Moreover, the efficiency of the sifting process and individual sieves $\left(w_{0}\right)$, depending on the grain diameter as well as the sifting efficiency of grain and chips through the holes of these sieves $\left(W_{i}\right)$, were calculated. The entire process of sifting abrasives was tested under the same conditions on workpieces with the same initial surface quality.

\section{EXPERIMENTAL PART}

\section{Materials}

A commercially available diamond was used (NOTA Ltd. with 15 wt \%) and $\mathrm{SiO}_{2}$ (Góradże Ltd. with 15 wt \%) as an abrasive a mixture of polymethylhydroborosiloxane $\left(\mathrm{SiO}_{2}\right)(85 \%$ by weight) with chips of the processed work- pieces material according to our own developed procedure. Abrasive grains were added in small portions to the polymer and then kneaded to obtain an even distribution of the abrasive grains in the paste. The abrasive grain was determined due to mesh scope (Tab. 1).

Complex geometries such as fluted inner surfaces have been processed for the purpose to study the mechanism of material removal and surface formation on polymeric materials.

The workpieces were made of acrylonitrile butadiene styrene copolymer (ABS), trade name ABS Extrafill Traffic White, producer 3D Jake. The number of workpieces $(\mathrm{M})$ was determined so that the radius of the grain tip rounding differed between the diamond and the $\mathrm{SiO}_{2}$ abrasive. The tip radius depended on the grain tip angle. The smaller the angle $(\gamma)$, the greater the amount of workpieces material. The abrasive grain radius is smaller in diamond than in $\mathrm{SiO}_{2}[19,27]$. Diamond grain $\left(\mathrm{M}_{\mathrm{d}}\right)<\mathrm{SiO}_{2}$ grain $\left(\mathrm{M}_{\mathrm{s}}\right)$.

\section{$\mathrm{T}$ a b l e 1. Characteristics of abrasive grain scope}

\begin{tabular}{l|c|c}
\hline $\begin{array}{c}\text { Abrasive grain } \\
\text { material }\end{array}$ & Mesh scope & $\begin{array}{c}\text { Average grain } \\
\text { diameter, } \mu \mathrm{m}\end{array}$ \\
\hline Diamond & 280 & $25-32$ \\
$\mathrm{SiO}_{2}$ & 220 & $32-53$ \\
$\mathrm{SiO}_{2}$ & 150 & $53-106$ \\
$\mathrm{Diamond}_{\mathrm{SiO}}$ & 70 & $106-212$ \\
Diamond $/ \mathrm{SiO}_{2}$ & 40 & $212-425$ \\
Diamond/SiO & 24 & $425-850$ \\
Diamond & 16 & $850-1400$ \\
\hline
\end{tabular}

\section{Sifting process description}

The process was carried out using vibrating screen. The screen structure is column-shaped. The type of drive used allows the vertical vibrations elimination of the screen, when correctly set. On the metal base of the screen, a column of $400 \mathrm{~mm}$ diameter circular screens sieves supported on springs was mounted. The column assembles from segments between which sieves and devices for cleaning them are placed. The chutes discharge the material from the screens to the discharge nozzles and then to the fraction collectors. On the base rests the first lower segment with a conical funnel. The column is covered with a flat cover with nozzles for feeding grain and removing dust. The station of the sifter is shown in Fig. 2. Circular screens, embedded in profiled frames, were used to test the sifting efficiency of the abrasive paste successive fractions (polymer + abrasive grain + processed material filings) through the holes in the sieve. The characteristics of the sheet metal sieves are presented in Table 2. The grains were divided according to their diameter into individual fractions: $0.025-0.035 ; 0.035-0.053 ; 0.053-0.106$; $0.106-0.212 ; 0.212-0.425 ; 0.425-0.850 \mathrm{~mm}$. 
T a b l e 2. Characteristics of sieves with circular holes

\begin{tabular}{c|c|c|c|c}
\hline $\begin{array}{c}\text { Sieve hole diameter } \\
\mathrm{mm}\end{array}$ & Mesh scope & $\begin{array}{c}\text { Sieve holes area } \\
\mathrm{mm}^{2}\end{array}$ & $\begin{array}{c}\text { Sieve clearance } \\
\%\end{array}$ & $\begin{array}{c}\text { Sieve quantity } \\
\text { pcs }\end{array}$ \\
\hline 0.025 & 498 & 38447 & 26 & 48289432 \\
0.032 & 403 & 25195 & 27 & 31644920 \\
0.053 & 299 & 13841 & 35 & 17384296 \\
0.106 & 156 & 3764 & 38 & 4727584 \\
0.212 & 79 & 977 & 39 & 1227112 \\
0.425 & 39 & 237 & 38 & 297672 \\
0.850 & 22 & 76 & 48 & 95456 \\
1.400 & 15 & 33 & 57 & 41448 \\
\hline
\end{tabular}

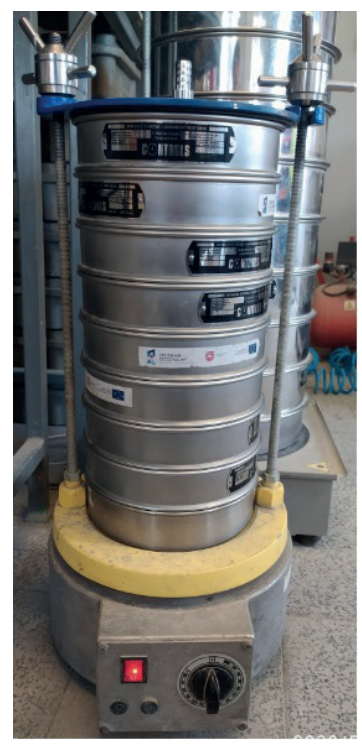

Fig. 2. Multi-level screen for abrasive grain with side vibrators station

The sifting process was carried out as follows. $1 \mathrm{~kg}$ of used abrasive paste was loaded into the screen, which contained diamond grains and polymer chips with the fraction of 280-24 Mesh (sieve-diamond) or $\mathrm{SiO}_{2}$ grains and polymer chips with the fraction of 220-24 Mesh (sieve- $\mathrm{SiO}_{2}$ ), and after time $\tau$ the apparatus was stopped and the individual fractions passed through the sieve were weighed. The view of the abrasive grain on a sieve with a hole diameter of $0.212 \mathrm{~mm}$ is presented in Fig. 3 .

\section{RESULTS AND DISCUSSION}

The number of grains that pass through the sieve, for the given time was measured. The sifting efficiency for the individual sieves was calculated as follows (Eqs. 1-6):

Sifting efficiency:

$$
W_{i}=\frac{m_{n}}{\tau_{p}}
$$

Calibrator surface:

$$
F=\frac{\pi \cdot D^{2}}{4}
$$

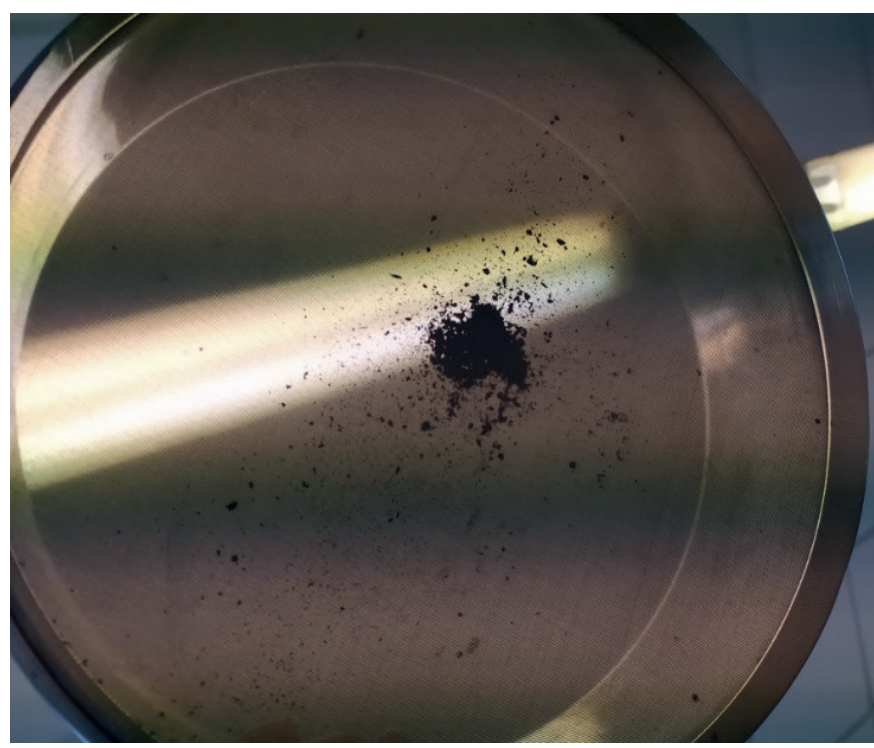

Fig. 3. View of the abrasive grain on a sieve with holes diameter of $0.212 \mathrm{~mm}$

Mesh sieve:

$$
F_{i, o}=p_{i} \cdot \frac{\pi \cdot D^{2}}{4}
$$

Efficiency of sieving through the individual mesh sieve:

$$
w_{i, o}=W_{i} \cdot p_{i}
$$

Mass flow velocity:

$$
G_{i}=\frac{w_{i}}{F}
$$

Mass flow velocity through the mesh sieve

$$
g_{i, o}=G_{i} \cdot p_{i}
$$

The discharge of granular material through the mesh sieve from the tank is described by the relationship (Eq. 7):

$$
W_{i}=f_{i} \cdot u=n \cdot \frac{\pi \cdot d_{o}^{2}}{4} \varphi \sqrt{a \cdot g \cdot d_{o}}=A \cdot d_{o}^{2.5}
$$


and it is analogous to the equations obtained as a result of the research, describing the passage of the spent paste through the mesh sieve [28-32].

Where:

$W_{i}$ - sifting efficiency, $\mathrm{kg} / \mathrm{h}$

$w_{0}$ - individual mesh sifting efficiency, $\mathrm{kg} / \mathrm{h}$

$\mathrm{kg}$

$m_{n}$ - the mass of grains passed through the next sieve,

$m_{n}=M_{p\left(d_{-} s\right)}-m_{m}$

$M_{p}$ - mass of abrasive paste, $\mathrm{kg}$

$m_{n}-$ mass of abrasive grain and polymer chips, $\mathrm{kg}$

$\tau_{p}$ - time needed for the grains to pass through the sieve, $\mathrm{h}$

$D$ - calibrator diameter, $\mathrm{m}$

$p$ - mesh sieve clearance, $\%$

$f_{i}$ - surface discharge, $\mathrm{m}^{2}$

$u=\varphi \sqrt{a \cdot g \cdot d_{o}}-$ mesh linear velocity for the discharge of the granular material from the hopper, $\mathrm{m} / \mathrm{s}$

$n$ - quantity of mesh sieves, $n=1,2,3, \ldots$

$A, a$ - constant,

$\varphi$ - coefficient discharge,

$g$ - coefficient gravity, $\mathrm{m} / \mathrm{s}^{2}$

The equations describing the passage of polymer grains and chips through the sieves depending on the fraction diameter are presented in Tables 3 and 4. As shown in Fig. 4, the apparent sifting efficiency increased as the grain size decreased. The maximum efficiency $(319 \mathrm{~kg} / \mathrm{h})$ was achieved for a sieve with a mesh sieve of $0.85 \mu \mathrm{m}$ and a grain size of $32 \mu \mathrm{m}$, with the greatest grain size reduction from 1400 to $10 \mu \mathrm{m}$.

It is clear from Fig. 5 that the efficiency of performance increased with a reduction in the size of the sieves holes. Moreover, for a given sieve holes diameter, the sifting efficiency of the grains, grains and polymer chips fractions

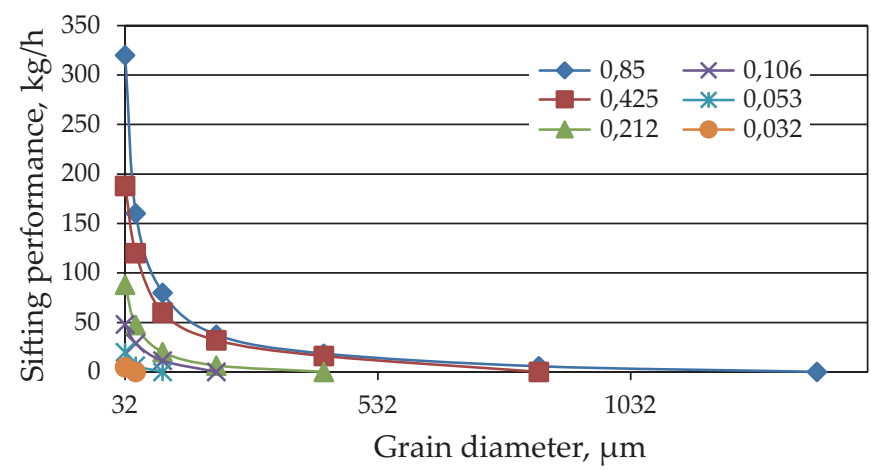

Fig. 4. Sifting efficiency of grain through individual sieve depending on the average diameter of abrasive grain

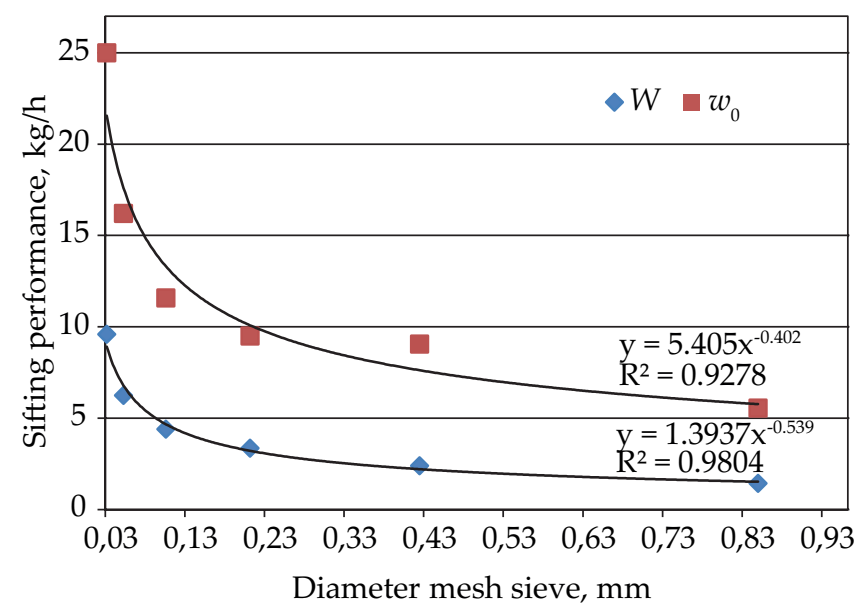

Fig. 5. Sifting efficiency of grain through the smallest sieve for the given fraction depending on the diameter of sieve holes

T a b l e 3. Regression equations of sifting efficiency for individual sieves, depending on the diameter of the fraction of grains for the angle of setting of sieve position angle amounting to $42.5^{\circ}$

\begin{tabular}{c|c|c}
\hline Mesh sieve diameter, $\mathrm{mm}$ & Regression equations & Coefficient of correlation \\
\hline 0.850 & $y=13.743 x^{2}-157.46 x+443,77$ & 0.9764 \\
0.425 & $y=7.7857 x^{2}-91.071 x+270$ & 0.9956 \\
0.212 & $y=5.8857 x^{2}-56.994 x+138.56$ & 0.9991 \\
0.106 & $y=2 x^{2}-26.16 x+72.4$ & 0.9993 \\
0.053 & $y=3.6 x^{2}-24.4 x+40.8$ & 0.9995 \\
0.032 & $y=-4.8 x+9.6$ & 0.9999 \\
\hline
\end{tabular}

$\mathrm{T}$ a b l e 4. Sifting efficiency of grain through the smallest sieve for the given fraction

\begin{tabular}{c|c|c|c|c|c|c|c}
\hline$M_{d^{\prime}} \mathrm{mm}$ & $p, \%$ & $F, \mathrm{~m}^{2}$ & $F_{0^{\prime}} \mathrm{m}^{2}$ & $W, \mathrm{~kg} / \mathrm{h}$ & $w_{0^{\prime}} \mathrm{kg} / \mathrm{h}$ & $G, \mathrm{~kg} / \mathrm{m}^{2} \mathrm{~h}$ & $g_{0^{\prime}} \mathrm{kg} / \mathrm{m}^{2} \mathrm{~h}$ \\
\hline 0.85 & 25.9 & 0.126 & 0.033 & 1.44 & 5.56 & 11.46 & 44.27 \\
0.425 & 26.5 & 0.126 & 0.033 & 2.40 & 9.06 & 19.11 & 72.11 \\
0.212 & 35.4 & 0.126 & 0.044 & 3.36 & 9.49 & 26.75 & 75.57 \\
0.106 & 38.0 & 0.126 & 0.048 & 4.40 & 11.58 & 35.03 & 92.19 \\
0.053 & 38.5 & 0.126 & 0.048 & 6.24 & 16.21 & 49.68 & 129.04 \\
0.032 & 38.4 & 0.126 & 0.048 & 9.60 & 25.00 & 76.43 & 199.04 \\
\hline
\end{tabular}




\section{CONCLUSION}

It has been shown that spent polymeric abrasive paste can be successfully regenerated by sifting through vibrating screens using specific process parameters and reused in the abrasive flow machining. The sifting efficiency of individual sieves depends on the size of abrasive grains and polymer chips as well as the characteristics of the sieve used, which is described by the regression presented in Table 3. The lowest efficiency of the sifting process was obtained using a sieve with the diameter of the holes equal to the diameter of the grain and the polymer chips of the given fraction.

\section{REFERENCES}

[1] Pintu K., Sudhansu S.P.: Measurement 2018, 119, 270. https://doi.org:10.1016/j.measurement.2018.01.060

[2] Flizikowski J., Macko M.: Polymers 2021, 13 (5), 713. https://doi.org/10.3390/polym13050713

[3] Nowacka A., Klepka T.: Mechanik 2019, 4, 7. https://doi.org/10.17814/mechanik.2019.4.32

[4] Hashimoto F., Yamaguchi H., Krajnik P. et al.: CIRP Annals - Manufacturing Technology 2016, 65, 597. https://doi.org/10.1016/j.cirp.2016.06.003

[5] Macko M., Tyszczuk K., Śmigielski G., Mroziński A.: "The use of CAD applications in the design of shredders for polymers", MATEC Web of Conferences, 2018 , p. 3. https://doi.org/10.1051/MATECCONF/201815702027

[6] Bremerstein T., Potthoff A., Michaelis A. et al.: Wear 2015, 342-343, 44. https://doi.org/10.1016/j.wear.2015.08.013

[7] Nowacka A., Klepka T.: Physicochemical Problems of Mineral Processing 2019, 55 (6), 1557. https://doi.org:10.5277/ppmp19085

[8] Sankar M., Jain V.K., Rajurkar K. P.: Procedia CIRP 2018, 68, 529. https://doi.org/10.1016/j.procir.2017.12.108

[9] Toth G., Nagy D., Bata A. et al.: Journal of Physics Conference Series 2017, 175, 1. https://doi.org/10.1088/1757-899X/175/1/012056

[10] Macko M., Tyszczuk K., Mrozinski A., Śmigielski G.: "Utility of an unitary-shredding method to evaluate the conditions and selection of constructional features during grinding", MATEC Web of Conferences, 2018, p. 43. https://doi.org/10.1051/MATECCONF/201815705016

[11] Wang C., Cheng K.C., Chen K.Y. et. al.: Procedia CIRP 2018, 68, 523. https://doi.org/10.1016/j.procir.2017.12.107

[12] Butola R., Jain R.: Materials Today: Proceedings 2018, 5, 4720. https://doi.org/10.1016/j.matpr.2017.12.044

[13] Wang R., Lim P., Heng L. et al.: Materials 2017, 10, 1029. https://doi.org/10.3390/ma10091029
[14] Wang A.C., Cheng K.C., Chen K.Y. et al.: Procedia CIRP 2018, 68, 523. https://doi.org/10.1016/j.procir.2017.12.107

[15] Korzeniowski M.: "Metodyka eksperymentu”, Wydawnictwo Naukowe PWN, Warszawa 2017, p. 132.

[16] Pei X.O., Friedrich K.: Reference Module in Materials Science and Materials Engineering 2016, 1. https://doi.org/10.1016/B978-0-12-803581-8.03074-5

[17] Macko M., Mroziński A., Prentki A.: „Simulations CAE of wood pellet machine", MATEC Web of Conferences 2019, p. 56. https://doi.org/10.1051/MATECCONF/201925402028

[18] Kumar S., Hiremath S.S.: Procedia Technology 2016, 25, 1297. https://doi.org/10.1016/j.protcy.2016.08.224

[19] Hashimoto F., Yamaguchi H., Krajnik P.: CIRP Annals - Manufacturing Technology 2016, 65, 597. https://doi.org/10.1016/j.cirp.2016.06.003

[20] Onieszczuk- Świercz R., Świercz R., Dąbrowski L.: Mechanik 2016, 8-9, 26. https://doi.org/10.17814/mechanik.2016.8-9.280

[21] Macko M., Mrozinski A.: „Work parameters research of wood pellet machine" AIP Conference Proceedings 2019, p. 2077. https://doi.org/10.1063/1.5091899

[22] Ławińska K., Modrzewski R.: „Sieve holes blocking in screens used in mechanical processing of useful minerals", Technologia i Jakość Wyrobów, Łódź 2015, p. 1.

[23] Macko M., Mroziński A., Prentki A.: "Simulations CAE of wood pellet machine" MATEC Web of Conferences 2019, p. 254. https://doi.org/10.1051/MATECCONF/201925402028

[24] Zaborski S., Stechnij T., Masalski J., Poroś D.: „Właściwości fizykochemiczne powierzchni wybranych materiałów po obróbce strumieniowo-ściernej", Zeszyty naukowe Politechniki Rzeszowskiej Mechanika 2017, 295, p. 555. https://doi.org:10.7862/rm.2017.52

[25] Wei H., Peng C., Gao H. et al.: International Journal of Machine Tools and manufacture 2019, 138, 66. https://doi.org/10.1016/j.ijmachtools.2018.12.003

[26] Han S., Salvatore F., Rech J. et al.: Journal of Manufacturing Processes 2020, 59, 248. https://doi.org:10.1016/j.jmapro.2020.09.065

[27] Macko M., Mroziński A.: „Computer Aided Design of Wood Pellet Machines", Proceedings of the $14^{\text {th }}$ International Scientific Conference: Computer Aided Engineering. CAE, Lecture Notes in Mechanical Engineering 2018, Springer, p. 454. https://doi.org/10.1007/978-3-030-04975-1_53

[28] Zhang Z., Zhang X., Liu X. et al: Procedia CIRP 2020, 89, 282. https://doi.org/10.1016/j.procir.2020.05.153

[29] Bararya R., Babbar A., Jain V. et al: Processes 2020, 50, 266. https://doi.org/10.1016/j.jmapro.2019.12.051 
[30] Kum C.W., Wu C.H., Wan S. et al: Journal of materials processing Technology 2020, 282, 116. https://doi.org/10.1016/j.jmatprotec.2020.116704

[31] Han S., Salvatore F., Bajolet J.: Precision Engeering 2020, 64, 20.

https://doi.org/10.1016/j.precisioneng.2020.03.006
[32] Garbacz T., Tor-Światek A. Samujło B.: „Właściwości mechaniczne i cieplne tworzyw polimerowych", Wydawnictwo Politechniki Lubelskiej, Lublin 2017, p. 78.

Received 11 VI 2021. 